\title{
On the distribution of Siphonops paulensis Boettger, 1892 (Gymnophiona: Siphonopidae): four new Brazilian state records
}

\author{
Tamí Mott $^{1 *}$, Larissa Lima Correia ${ }^{2,3}$, João Paulo Felix Augusto de Almeida ${ }^{2,4}$, Barnagleison Silva \\ Lisboa $^{2,3}$ and Míriam Camargo Guarnieri ${ }^{5}$
}

1 Universidade Federal de Alagoas, Instituto de Ciências Biológicas e da Saúde, Avenida Lourival Melo Mota, s/nº Tabuleiro, CEP 57072970, Maceió, AL, Brazil

2 Museu de História Natural da Universidade Federal de Alagoas, Avenida Aristeu de Andrade, Farol, CEP 57051-090, Maceió, AL, Brazil

3 Universidade Federal de Pernambuco, Programa de Pós-Graduação em Biologia Animal, Avenida Professor Nelson Chaves, s/nº, Cidade Universitária, CEP 50670-420, Recife, PE, Brazil

4 Universidade Federal de Alagoas, Programa de Pós-Graduação em Diversidade Biológica e Conservação nos Trópicos, Avenida Lourival Melo Mota, s/nº, Tabuleiro, CEP 57072-970, Maceió, AL, Brazil

5 Universidade Federal de Pernambuco, Departamento de Zoologia, Avenida Professor Nelson Chaves, s/n ${ }^{\circ}$, Cidade Universitária, CEP 50670-420, Recife, PE, Brazil

* Corresponding author. E-mail: tamimott@hotmail.com

\begin{abstract}
Siphonops paulensis Boettger, 1892 is a Neotropical siphonopid caecilian widely distributed in South America. Herein, we fill knowledge gaps in the distribution of $S$. paulensis mostly in northeastern Brazil, including four new state records.
\end{abstract}

Key words: Boettger's caecilian; Bahia; Paraíba; Pará; Pernambuco; Brazil

The Neotropical genus Siphonops Wagler, 1828 currently includes five species: S. annulatus (Mikan, 1820), S. hardyi Boulenger, 1888, S. paulensis Boettger, 1892, S. insulanus Ihering, 1911 and S. leucoderus Taylor, 1968. Among them, $S$. annulatus and $S$. paulensis exhibit very similar morphology and are widely distributed in South America (Taylor 1968; Frost 2015). Siphonops paulensis has been recorded in Argentina, Bolivia, Brazil and Paraguay (Taylor 1968; Frost 2015). In Brazil, this species can be found mainly across central and south portions of the country (Taylor 1970), but recent studies have reported a few additional records from northeastern Brazil (e.g., Loebmann and Haddad 2010; Valdujo et al. 2011; Miranda et al. 2012; Santana et al. 2015). Herein, we continue to fill knowledge gaps in the distribution of S. paulensis, mostly in northeastern Brazil.

Eighteen specimens of $S$. paulensis were examined by one of us (TM) during a survey on caecilians in seven Brazilian biological collections: Coleção Herpetológica do Departamento de Botânica, Ecologia e Zoologia da Universidade Federal do Rio Grande do Norte (CHBEZ), Coleção Herpetológica da Universidade Federal da
Paraíba (CHUFPB), Coleção Herpetológica da Universidade Federal Rural de Pernambuco (CHUFRPE), Museu de Ciências Naturais da Pontifícia Universidade Católica de Minas Gerais (MCNAM), Universidade Estadual de Feira de Santana (UEFS), Universidade Federal da Bahia (UFBA) and Universidade Federal de Minas Gerais (UFMG). These specimens represent four new state records for Brazil (Bahia, Pará, Paraíba and Pernambuco states) and add five new municipality records in Minas Gerais state and one in Rio Grande do Norte state for the distribution of $S$. paulensis (Figure 1). Vouchers, geographic coordinates, body lengths and the number of body annuli of $S$. paulensis specimens are shown in Table 1.

According to Taylor (1968), S. annulatus and $S$. paulensis differ in the number of body annuli following the collars (78-98 in the first and 100-118 in the later) and the coloration (bluish-black to slate in the first and slate-blue to live slate or brownish to violet-brown in the latter). The taxonomic identification of all 18 specimens was made following Taylor (1968).

Four new Brazilian state records of $S$. paulensis are reported here (Bahia, Pará, Paraíba and Pernambuco; Figure 1). The record for Bahia is from Serra do Orobó at Ruy Barbosa municipality, whereas the nearest specimen previously collected is from Simão Dias, Sergipe State (ca. $350 \mathrm{~km}$ northeast; Santana et al. 2015). The northernmost record of $S$. paulensis in Brazil is our new record for the Pará state, at Oriximiná municipality, ca. $1,300 \mathrm{~km}$ north of the nearest location known for the species at Cláudia, Mato Grosso state (Faria and Mott 2011). The record for Paraíba is in João Pessoa municipality, ca. $175 \mathrm{~km}$ north of the closest 


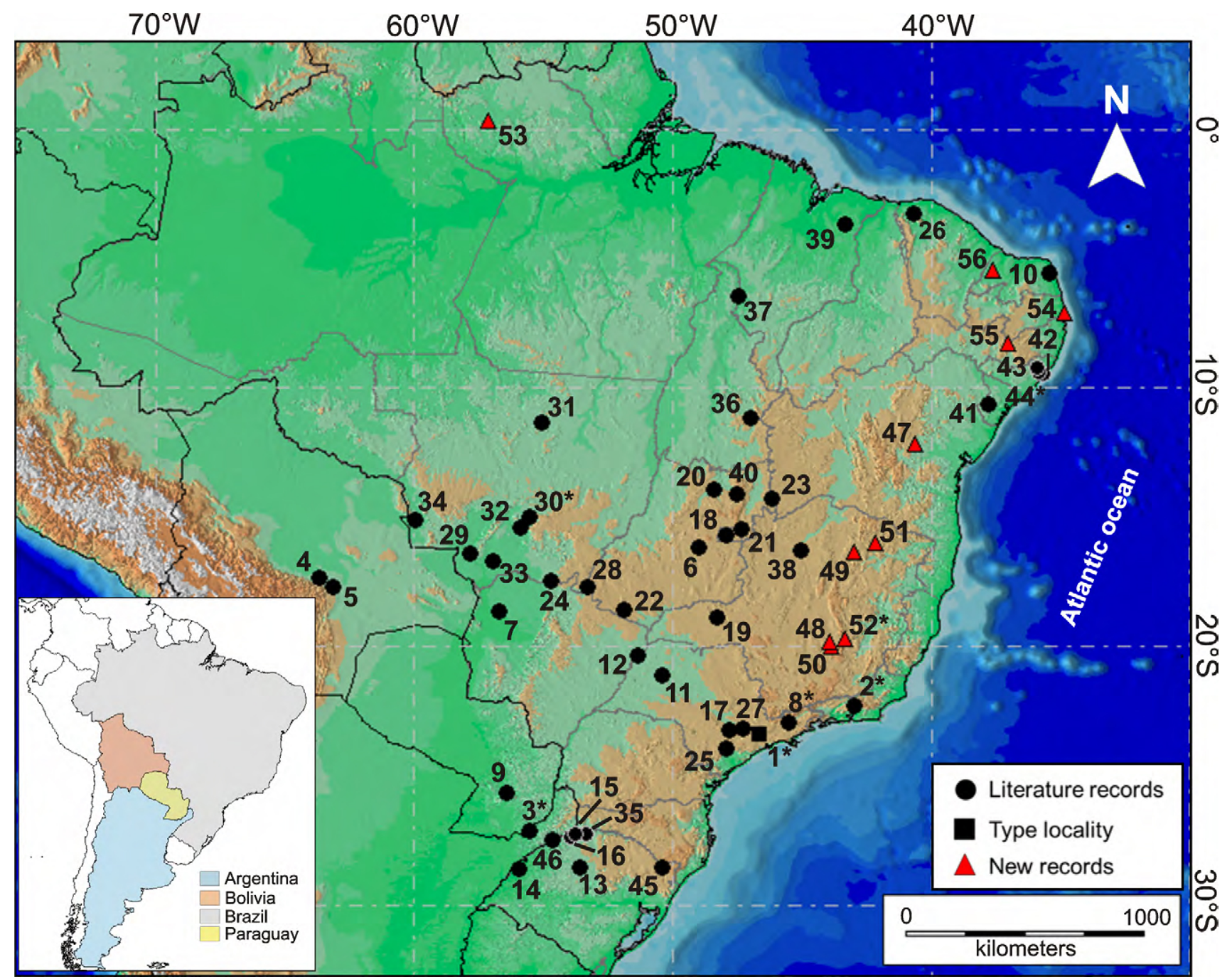

Figure 1. Distributional records of Siphonops paulensis. Circles = literature records; square = type locality; triangles = new records; asterisks = localities where there are sympatry with Siphonops annulatus. Localities and references: 1. São Paulo, SP, Brazil (Boettger 1892); 2. Teresópolis, RJ, Brazil (Sawaya 1937); 3. San Ignacio, Argentina (Dunn 1942); 4. Buena Vista, Bolivia (Dunn 1942); 5. Santa Cruz de la Sierra, Bolivia (Dunn 1942); 6. Anápolis, GO, Brazil (Dunn 1942); 7. Corumbá, MS, Brazil (Dunn 1942); 8. Taubaté, SP, Brazil (Dunn 1942); 9. Villarrica, Paraguay (Dunn 1942); 10. Ceará Mirim, RN, Brazil (Schmidt and Inger 1951); 11. Araçatuba, SP, Brazil (Species Link, collected in 1969); 12. Ilha Solteira, SP, Brazil (Species Link, collected in 1973); 13. Cruz Alta, RS, Brazil (Braun and Braun 1980); 14. São Borja, RS, Brazil (Braun and Braun 1980); 15. Tenente Portela, RS, Brazil (Braun and Braun 1980); 16. Três Passos, RS, Brazil (Species Link, collected in 1991); 17. Tatuí, SP, Brazil (Species Link, collected in 2000); 18. Brasília, DF, Brazil (Kokubum and Menin 2001); 19. Uberlândia, MG, Brazil (Kokubum and Menin 2001); 20. Minaçu, GO, Brazil (Souza et al. 2002); 21. Formosa, GO, Brazil (Schwartz et al. 2003); 22. Aporé, GO, Brazil (Vaz-Silva et al. 2007); 23. Mambaí, GO, Brazil (Cintra et al. 2009); 24. Sonora, MS, Brazil (Silva-Júnior et al. 2009); 25. São Miguel Arcanjo, SP, Brazil (Forlani et al. 2010); 26. Ibiapaba, CE, Brazil (Loebmann and Haddad 2010); 27. Itu, SP, Brazil (Species Link, collected in 2010); 28. Alto Taquari, MT, Brazil (Faria and Mott 2011); 29. Cáceres, MT, Brazil (Faria and Mott 2011); 30. Chapada dos Guimarães, MT, Brazil (Faria and Mott 2011); 31. Cláudia, MT, Brazil (Faria and Mott 2011); 32. Cuiabá, MT, Brazil (Faria and Mott 2011); 33. Poconé, MT, Brazil (Faria and Mott 2011); 34. Vila Bela de Santíssima Trindade, MT, Brazil (Faria and Mott 2011); 35. Frederico Westphalen, RS, Brazil (Lema and Martins 2011); 36. Almas, TO, Brazil (Valdujo et al. 2011); 37. Estreito, MA, Brazil (Species Link, collected in 2011); 38. São Romão, MG, Brazil (Species Link, collected in 2011); 39. Chapadinha, MA, Brazil (Miranda et al. 2013); 40. Alto Paraíso de Goiás, GO, Brazil (Species Link, collected in 2013); 41. Simão Dias, SE, Brazil (Santana et al. 2015 ); 42. Maceió, AL, Brazil (submitted); 43. Murici, AL, Brazil (submitted); 44. Rio Largo, AL, Brazil (submitted); 45. Bom Jesus, RS, Brazil (Species Link, no collection date); 46. Porto Mauá, RS, Brazil (Species Link, no collection date); 47. Serra do Orobó, Ruy Barbosa, BA, Brazil (this study); 48. Belo Horizonte, MG, Brazil (this study); 49. Grão Mogol, MG, Brazil (this study); 50. Nova Lima, MG, Brazil (this study); 51. Salinas, MG, Brazil (this study); 52 . São Gonçalo do Rio Abaixo, MG, Brazil (this study); 53. Oriximiná, PA, Brazil (this study); 54. João Pessoa, PB, Brazil (this study); 55. Arcoverde, PE, Brazil (this study); 56. Felipe Guerra, RN, Brazil (this study).

location previously known for the species at Ceará Mirim, Rio Grande do Norte state (Schmidt and Inger 1951). The record for Pernambuco is located at Arcoverde municipality, ca. $150 \mathrm{~km}$ northwest from the nearest site of occurrence of the species at Murici, Alagoas state (submitted).
For Minas Gerais and Rio Grande do Norte states, we add five and one new municipality records of Siphonops paulensis (Grão Mogol, Salinas, Belo Horizonte, Nova Lima, São Gonçalo do Rio Abaixo and Felipe Guerra, respectively). Grão Mogol and Salinas are ca. $220 \mathrm{~km}$ and $306 \mathrm{~km}$ east and Belo Horizonte, Nova Lima and São Gonçalo do Rio 
Table 1. Localities and morphological data of the new records of Siphonops paulensis in Brazil. Acronyms of Zoological Collections are represented by: CHBEZ = Coleção Herpetológica do Departamento de Botânica, Ecologia e Zoologia da Universidade Federal do Rio Grande do Norte, CHUFPB = Coleção Herpetológica da Universidade Federal da Paraíba, CHUFRPE = Coleção Herpetológica da Universidade Federal Rural de Pernambuco, MCNAM = Museu de Ciências Naturais da Pontifícia Universidade Católica de Minas Gerais, UFES = Universidade Estadual de Feira de Santana, UFBA = Universidade Federal da Bahia, UFMG = Universidade Federal de Minas Gerais. States are represented by: BA = Bahia state, MG = Minas Gerais state, PA = Pará state, PB = Paraíba state, $\mathrm{PE}=$ Pernambuco state, $\mathrm{RN}=$ Rio Grande do Norte state.

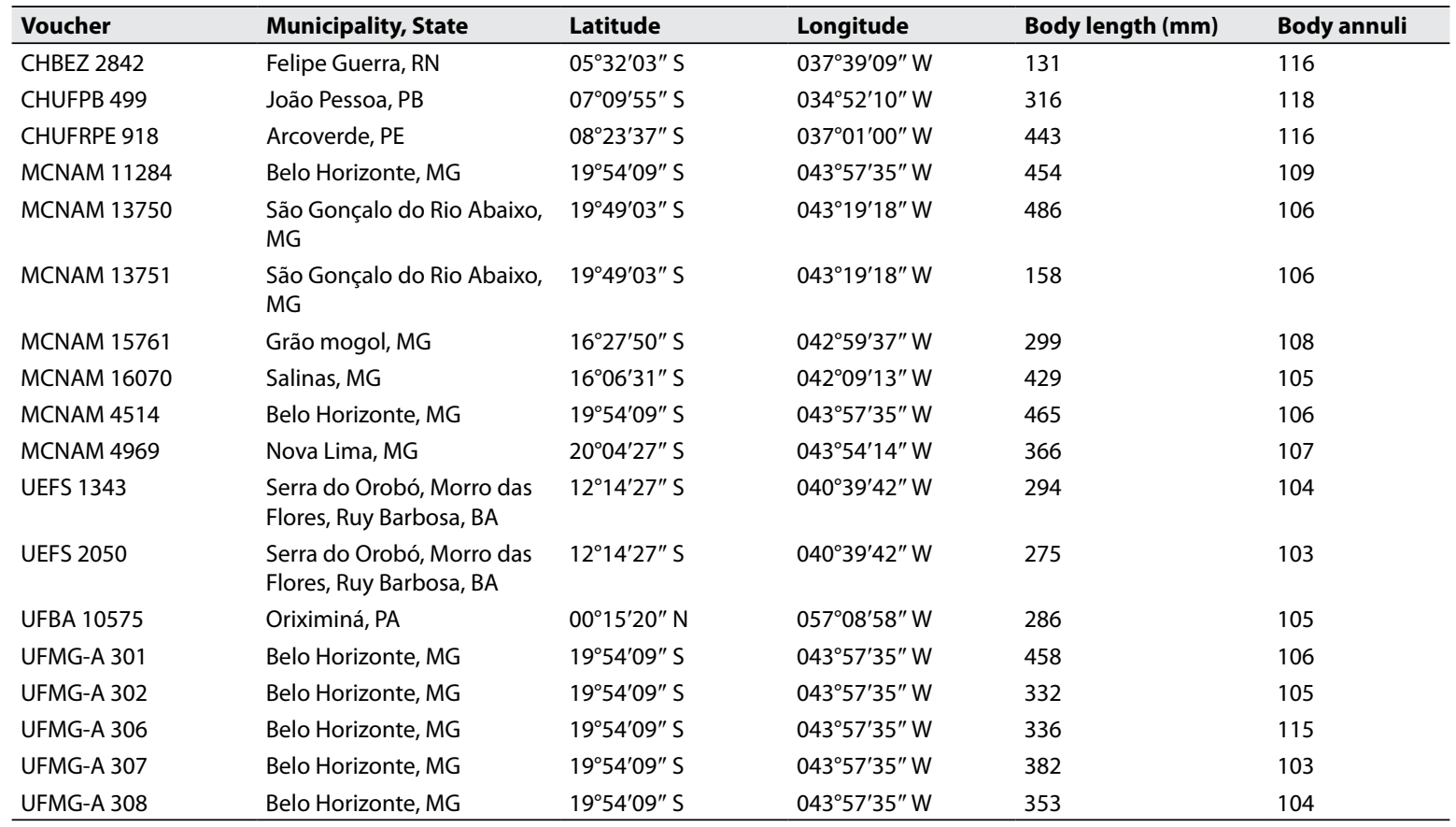

Abaixo are ca. $405 \mathrm{~km}, 425 \mathrm{~km}$, and $420 \mathrm{~km}$ southeast from the nearest location at São Romão, Minas Gerais state (Species Link 2012). Felipe Guerra is ca. $245 \mathrm{~km}$ west from the closest location previously known for the species at Ceará Mirim municipality, Rio Grande do Norte state (Schmidt and Inger 1951) (Figure 1).

We found a misidentification rate of $66 \%$ (12 from 18) of $S$. paulensis specimens in seven Brazilian collections, which have raised our concerns regarding the veracity of distribution records of $S$. paulensis and S. annulatus in articles that do not provide meristic data (Braun and Braun 1980; Kokubum and Menin 2001; Schwartz et al. 2003; Vaz-Silva et al 2007; Cintra et al. 2009; Silva et al. 2009; Forlani et al. 2010; Faria and Mott 2011; Valdujo et al. 2011) or voucher specimens (Schwartz et al. 2003; Vaz-Silva et al. 2007; Silva et al. 2009; Lema and Martins 2011; Valdujo et al. 2011).The sympatry of these species in at least seven localities plus the discrete morphological differentiation between them reinforces our apprehension regarding their taxonomic validity and accurate identification. Dunn (1942) already reported both species sympatric at two localities (Taubaté, São Paulo state and Teresópolis, Rio de Janeiro state), and Farias and Mott (2011) at one locality (Chapada dos Guimarães National Park, Mato Grosso state). A taxonomic revision of $S$. annulatus and $S$. paulensis is urgently needed. We recommend the collection of tissue samples in order to generate further morphological and molecular data to address this question.

\section{ACKNOWLEDGEMENTS}

We thank Eliza M. X. Freire from CHBEZ, Daniel O. Mesquita from CHUFPB, Ednilza M. dos Santos from CHUFRPE, Luciana B. Nascimento from MCNAM, Flora Juncá from UEFS, Marcelo F. Napoli from UFBA and Paulo C. A. Garcia from UFMG for the loan of specimens. Additionally, we thank FAPEAL for the financial support and Richard Ladle for English revision.

\section{LITERATURE CITED}

Boettger, O. 1892. Katalog der Batrachier-Sammlung im Museum der Senckenbergischen Naturforschenden Gesellshaft in Frankfurt am Main. Frankfurt am Main: Gebrüder Knauer. 140 pp.

Braun, P.C. and C.A.S. Braun. 1980. Lista prévia dos anfíbios do Estado do Rio Grande do Sul, Brasil. Iheringia Série Zoologia 56: 121-146. http://biodiversitylibrary.org/page/34562279

Cintra, C.E.D., H.L.R. Silva and N.J. Silva-Júnior. 2009. Herpetofauna, Santa Edwiges I and II hydroelectric power plants, state of Goiás, Brazil. Check List 5(3): 570-576. http://www.checklist.org.br/ getpdf?SL113-08

Dunn, E.R. 1942. The American caecilians. Bulletin of the Museum of Comparative Zoology 91: 437-540. http://biodiversitylibrary. org/page/4788854

Faria, H.A.B. and T. Mott. 2011. Geographic distribution of caecilians (Gymnophiona, Amphibia) in the state of Mato Grosso, Brazil with a new state record for Caecilia mertensi Taylor 1973. Herpetology Notes 4: 053-056. http://www.herpetologynotes. seh-herpetology.org/Volume4_PDFs/Faria\&Mott_Herpetology_Notes_Volume4_pages053-056.pdf

Forlani, M.C., P.H. Bernardo, C.F.B. Haddad and H. Zaher. 2010. Herpetofauna do Parque Estadual Carlos Botelho, São Paulo, Brasil. Biota Neotropica 10(3): 265-309. doi: 10.1590/S1676- 


\section{8}

Frost, D.R. 2015. Amphibian Species of the World: an Online Reference, Version 6.0. New York: American Museum of Natural History. Accessed at http://research.amnh.org/vz/herpetology/ amphibia, 2 August 2015.

Kokubum, M.N.C. and M. Menin. 2001. Geographic Distribution. Siphonops paulensis. Herpetological Review 32(1): 53-53.

Lema, T. and L.A. Martins. 2011. Anfíbios do Rio Grande do Sul: catálogo, diagnose, distribuição e iconografia. Porto Alegre: ediPUCRGS. 196 pp.

Loebmann, D. and C.F.B. Haddad. 2010. Amphibians and reptiles from a highly diverse area of the Caatinga domain: composition and conservation implications. Biota Neotropica 10(3): 227-256. doi: 10.1590/S1676-06032010000300026

Miranda, J.P., R.F. Matos, F.M. Scarpa and C.F.D. Rocha. 2013. New record and distribution extension of Siphonops paulensis (Gymnophiona: Siphonopidae) in the State of Maranhão, northeastern Brazil. Herpetology Notes 6: 327-329. http:// www.herpetologynotes.seh-herpetology.org/Volume6_PDFs/ Miranda_HerpetologyNotes_volume6_pages327-329.pdf

Santana, D.O., C.B. De-Carvalho, E.B. Freitas, G.S.S. Nunes and R.G. Faria. 2015. First record of Siphonops paulensis Boettger, 1892 (Gymnophiona: Siphonopidae) in the state of Sergipe, northeastern Brazil. Check List 11(1): 1531. doi: 10.15560/11.1.1531

Sawaya, P. 1937. Sobre o gênero Siphonops Wagler 1828 - Amphibia Apoda - com descripção de duas variedades novas: S. annulatus (Mikan) var. marmoratus e S. paulensis Boettg. var. maculatus. Boletim da Faculdade de Filosofia Ciências e Letras da Universidade de São Paulo 1: 225-263.

Schmidt, K.P. and R.F. Inger. 1951. Amphibians and reptiles of the Hopkins-Branner expedition to Brazil. Fieldiana Zoology 31(42): 439-465. doi: 10.5962/bhl.title.3198

Schwartz, E.F., A. Stucchi-Zucchi, C.A. Schwartz, L.C. Salomão. 2003. Skin secretion of Siphonops paulensis (Gymnophiona, Amphibia) forms voltage-dependent ionic channels in lipid membranes. Brazilian Journal of Medical and Biological Research 36(9): 1279-1282. doi: 10.1590/S0100-879X2003000900020

Silva-Júnior, N.J., C.E.D. Cintra, H.L.R. Silva, M.C. Costa, C.A. Souza, A.A. Pachêco-Júnior, F.A. Gonçalves. 2009. Herpetofauna, Ponte de Pedra Hydroelectric Power Plant, states of Mato Grosso and Mato Grosso do Sul, Brazil. Check List 5(3): 518-525. http:// www.checklist.org.br/getpdf?SL114-08h

Souza, I.F., H.L.R. Silva and N.J. Silva-Jr. 2002. Geographic Distribution. Siphonops paulensis. Herpetological Review 33(2): 146-47.

SpeciesLink. 2012. SpeciesLink. Centro de Referência em Informação Ambiental, CRIA. Electronic database accessed at http://splink. cria.org.br, 10 July 2015.

Taylor, E.H. 1968. Caecilians of the world: a taxonomic review. Lawrence: University of Kansas Press. 848 pp.

Taylor, E.H. 1970. Notes on Brazilian caecilians. The University of Kansas Science Bulletin 48(24): 855-860. doi: 10.5962/bhl. part.28907

Valdujo, P.H., A. Camacho, R.S. Recoder, M.T. Junior, J.M.B. Ghellere, T. Mott, P.M.S. Nunes, C. Nogueira and M.T. Rodrigues. 2011. Anfíbios da Estação Ecológica Serra Geral do Tocantins, região do Jalapão, Estados do Tocantins e Bahia. Biota Neotropica 11(1): 251-261. doi: 10.1590/S1676-06032011000100025

Vaz-Silva, W., A.G. Guedes, P.L. Azevedo-Silva, F.F. Gontijo, R.S. Barbosa, G.R. Aloísio and F.C.G. Oliveira. 2007. Herpetofauna, Espora Hydroelectric Power Plant, state of Goiás, Brazil. Check List 3(4): 338-345. doi: 10.15560/3.4.338

Author contributions: All authors contributed to write the paper, LLC, JPFAA and TM identified specimens and JPFAA made the map.

Received: 18 August 2015

Accepted: 9 April 2016

Academic editor: Natan Medeiros Maciel 